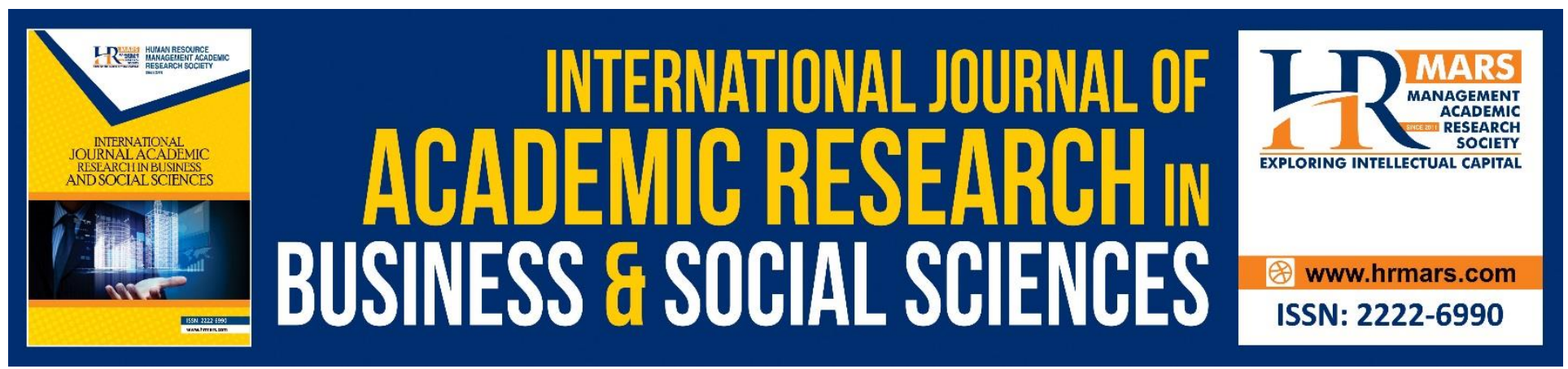

\title{
The Influence of Organizational Factors on Work Engagement among Academics at Malaysian Research Universities
}

\author{
Siti Zainab Tauhed, Roziah Mohd Rasdi, Bahaman Abu Samah \& Rahinah \\ Ibrahim
}

To Link this Article: http://dx.doi.org/10.6007/IJARBSS/v8-i10/4793

DOI: $10.6007 /$ IJARBSS/v8-i10/4793

Received: 18 Sept 2018, Revised: 13 Oct 2018, Accepted: 27 Oct 2018

Published Online: 10 Nov 2018

In-Text Citation: (Tauhed, Rasdi, Samah, \& Ibrahim, 2018)

To Cite this Article: Tauhed, S. Z., Rasdi, R. M., Samah, B. A., \& Ibrahim, R. (2018). The Influence of Organizational Factors on Work Engagement among Academics at Malaysian Research Universities. International Journal of Academic Research in Business and Social Sciences, 8(10), 973-988.

\section{Copyright: (C) 2018 The Author(s)}

Published by Human Resource Management Academic Research Society (www.hrmars.com)

This article is published under the Creative Commons Attribution (CC BY 4.0) license. Anyone may reproduce, distribute, translate and create derivative works of this article (for both commercial and non-commercial purposes), subject to full attribution to the original publication and authors. The full terms of this license may be seen

at: http://creativecommons.org/licences/by/4.0/legalcode

Vol. 8, No. 10, 2018, Pg. 973 - 988

http://hrmars.com/index.php/pages/detail/IJARBSS

JOURNAL HOMEPAGE

Full Terms \& Conditions of access and use can be found at http://hrmars.com/index.php/pages/detail/publication-ethics 


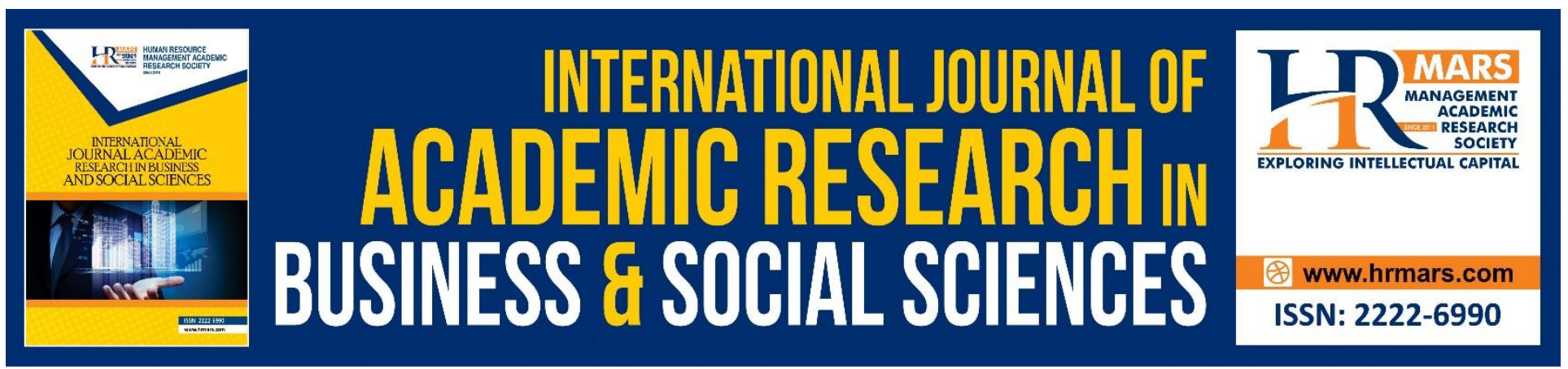

\title{
The Influence of Organizational Factors on Work Engagement among Academics at Malaysian Research Universities
}

\author{
Siti Zainab Tauhed ${ }^{1}$, Roziah Mohd Rasdi2*, Bahaman Abu Samah ${ }^{3} \&$ \\ Rahinah Ibrahim ${ }^{4}$ \\ 1,2,3 Department of Professional Development and Continuing Education, Faculty of Educational \\ Studies, Universiti Putra Malaysia, 43400 Serdang, Malaysia \\ ${ }^{4}$ Faculty of Design and Architecture, Universiti Putra Malaysia, 43400 Serdang, Malaysia
}

\begin{abstract}
The purpose of this paper is to examine the influence of organizational factors, i.e. organizational culture, transformational leadership and professional development on academics work engagement (WE) at Malaysian Research Universities (MRUs). The descriptive survey design was employed in this study and a questionnaire was used to collect data from the respondents. This study employed the proportionate stratified random sampling to select 381 sample of academics at MRUs. The data of this study were analyzed using the descriptive statistics and multiple regression. The results show that organizational culture, transformational leadership, and professional development significantly influence the work engagement of academics. This study is important for the Human Resource Development practitioners and university's management to identify factors and plan strategies of interventions to enhance academics engagement in their job. This paper contributes to a perceived gap in past studies that have little attention in investigating the influence of organizational factors on work engagement.
\end{abstract}

Keywords Work Engagement, Organizational Culture, Transformational Leadership And Professional Development

\section{Introduction}

Since three decades ago, work engagement has received significant attention from academics and practitioners. Engaged employees are valued and important to achieve individual work targets and subsequently assist the organizations to improve their performance especially in the current competitive world (Rich, Lepine, \& Crawford, 2010). Engaged employees are characterized as vigor, dedicated, and absorbed in their role performance (Schaufeli \& Bakker, 2004). Therefore, they have high levels of energy, enthusiastic, and fully immersed in their work. The term of engagement in work 
INTERNATIONAL JOURNAL OF ACADEMIC RESEARCH IN BUSINESS AND SOCIAL SCIENCES Vol. 8, No. 10, Oct. 2018, E-ISSN: 2222-6990 @ 2018 HRMARS

role performance was first mentioned in the Academy of Management Journal article, "Psychological Conditions of Personal Engagement and Disengagement at Work" (Kahn, 1990). Kahn's (1990) work has been the seminal paper for engagement until early 2000. The work engagement started to gain attention when the field of psychology was criticized as focusing too much on the negative aspect of mental illness rather than mental wellness (Bakker et al., 2008). This approach was criticized as it was not in tandem with the objective of psychology '. . . to begin to catalyze a change in the focus of psychology from pre-occupation only with repairing the worst things in life to also building positive qualities' (Seligman \& Csikszentmihalyi, 2000, p.5). Since then, the study about work engagement started to receive attention not only from psychologists but also scholars in the field or organizational behaviors and management as well as Human Resource Development (HRD) practitioners. Employees who are engaged in their work are believed would produce better output (Bakker \& Demerouti, 2014).

The focus of the study on work engagement ranging from to understand the concept of work engagement, the factors that enhance work engagement and the implications of work engagement. A number of leading studies in work engagement has examined the influence of proximal factors such as autonomy, social support, performance feedback, personal-related factors and job resources on work engagement (Schaufeli, 2013; Rich et al., 2010). However, studies in examining the influence of organizational factors such as organizational culture, transformational leadership and professional development on work engagement especially in the educational industries are still scarce and most of the studies about work engagement have been conducted in the western countries and in other industries. There is a need to understand the factors that could enhance work engagement, especially when dealing with high demanding and stressful work. This study focusing on the context of academics who are working at research universities where they are expected to produce high-quality research outputs which are associated with the standing of a university (Cadez, Dimovski, \& Groff, 2017; Frenken, Heimeriks, \& Hoekman, 2017).

This study aims to enhance the understanding about the factors that influence work engagement among academics at Malaysian Research Universities (MRUs). This context is chosen as it is directly related to the main role of a university in the knowledge production and knowledge dissemination (Dundar \& Lewis, 1998). In a profession that is very demanding, work engagement among employees is very crucial. Therefore, this study is timely to investigate the level of work engagement among academics of MRUs. There was a changing focus from teaching to researchintensive at MRUs as the Malaysian government has set a target for Malaysia to become a hub for knowledge and innovation through Research and Development (R\&D) as delineated in the National Higher Education Plan beyond 2020 and the Malaysia Education Blueprint 2015-2025 (Higher Education). Following this agenda, the Malaysian government has implemented higher educational system transformation to strengthen the research activities in order to have more research outputs. As a move to establish the research-oriented environment, the government has recognized five universities as MRUs since 2006 with the aim to improve the standing of the Malaysian Universities through intensification of research activities and outputs (Basarudin, Yeon, Yaacob, \& Rahman, 2016). There are Universiti Malaya (UM), Universiti Kebangsaan Malaysia (UKM), Universiti Sains Malaysia (USM), Universiti Teknologi Malaysia (UTM), and Universiti Putra Malaysia (UPM). 
This transformation leads academics to encounter high levels of work stress (Noor \& Ismail, 2016). Such work setting may disengage academics from performing their research activities. Consequently may lead to dissatisfaction (Winefield \& Jarrett, 2001) and have the intention to leave the university (Idris, 2011). They are also more prone to suffer from physical and/or mental health impairment (Bakker et al., 2010). A study by Noor and Ismail (2016) among academics at one of the MRUs found that academics of MRUs are in stressful condition especially to achieve and accomplish the target set by the universities in research in comparison to teaching. In the current economic downturn, academics' job performance in research remains highly expected (Bentley, 2015; Bland, Center, Finstad, Risbey, \& Staples, 2005). Such situation has greatly affected academics work engagement in their research activities that consequently affect the research performance (Basarudin et al., 2016; Ahmad, Farley, \& Naidoo, 2012).

Based on the above discussion and in order to focus on how to instill positivity among academics in managing the demanding work related to research, it is paramount to examine factors that influence and motivates academics in their everyday work. Therefore, this study aims to examine: (i) the level of work engagement of academics at MRUs; and (ii) the organizational predictors (organizational culture, transformational leadership, and professional development) of academics' work engagement. Such context is paramount for further investigation and provides insights into the organizational factors which can be utilized in the university intervention programs. Such programs are beneficial towards uplifting the performance of academics, faculty, and university.

\section{Conceptualizing Work Engagement}

Based on an extensive literature review, there is no consensus in conceptualizing work engagement. The conceptualization varies based on how work engagement is perceived. It started with Kahn's (1990) work about personal engagement that specifically referring to the individual investment of energy and soul in performing their job. There were several attempts to conceptualize work engagement. Firstly, work engagement is described as a manifestation of the psychological state by individual employees in work role performance. They invested and expressed themselves physically, cognitively and emotionally in performing their work roles (Kahn, 1990; Rich et al. 2010; May, Gilson, \& Harter, (2004). Secondly, other scholars regard engagement as the antipode of burnout where burnout and engagement are at opposite ends of a spectrum (Bakker et al., 2008; Maslach et al. 2001). Scholars from this school of thought were using the same instrument to measure job burnout and job engagement. Job engagement is conceptualized as an individual motivational state that is reflected through three dimensions, i.e. energy, involvement, and efficacy which are the antonym of job burnout dimensions, i.e. is exhaustion, cynicism, and ineffectiveness (Maslach et al., 2001). However, Schaufeli et al. (2002) argued that job engagement and job burnout are not the exact antitheses. This is due to the fact that it does not necessarily mean that when an employee is not engaged, they are burnout and vice versa (Schaufeli \& Bakker, 2004). Accordingly, Schaufeli et al. (2002) conceptualized work engagement as fulfilling, positive, continuous work-related state of mind that is reflected through vigor, dedication, and absorption which refers to the third attempt in conceptualizing work engagement. They argued that job engagement should be measured independently with different instruments and they developed the Utrecht Work Engagement Scale 
INTERNATIONAL JOURNAL OF ACADEMIC RESEARCH IN BUSINESS AND SOCIAL SCIENCES Vol. 8, No. 10, Oct. 2018, E-ISSN: 2222-6990 @ 2018 HRMARS

(UWES) $(2002,2006)$ to measure work engagement that consists of three dimensions, i.e. vigor, dedication, and absorption.

Based on the above discussion, it is clear that the conceptualization of work engagement varies. Kahn (1990), Rich et al. (2010) and May et al. (2004), conceptualized work engagement as investing full self in work performance. On the other hand, the second and third attempt conceptualized work engagement as positive affective state and state of mind respectively. It is worth noting that according to Zigarmi, Nimon, Houson, Witt, and Diehl (2009), there is an underlying consensus in defining work engagement which it should reflect the multidimensional structure that has a connection with employees' work on multiple levels. Therefore, in this study, Kahn's (1990) conceptualization of work engagement is used as it is more comprehensive (Bailey, Madden, Alfes, \& Flecther, 2015) and it involves multidimensional constructs. Since Kahn (1990) did not operationalize work engagement, this study adopted the definition of work engagement by Rich et al. (2010, p.619), i.e. a multidimensional motivational concept reflecting the simultaneous investment of an individual's physical, cognitive, and emotional energy in active, full work performance.

\section{Work engagement and its antecedents}

Past studies that examined the antecedents of work engagement has mostly used the Job Demand Resource Theory (JDRT) which is the extension of Job Demand Resource Model. The JDRT postulates that job resources influence work engagement (Bakker \& Demerouti, 2014). Job resources refer to those physical, social, or organizational aspects of the job that may: (1) reduce job demands and related psychological and physiological implications; (2) as a tool to attain work targets; or (3) enhance personal development, learning and growth (Bakker \& Demerouti, 2007). Examples of job resources are social support, supervisory coaching, and performance feedback. Most of the previous studies that used the JDRT has been examining the influences of proximal factors, such as perceived organizational support and perceived supervisor support and personal resources on job performance (Myhre, 2014; Xanthopoulou et al., 2009).

Nevertheless, Macey and Schneider (2008) and Kahn (2010) argued that distal factors also influence work engagement. The distal or contextual factors refer to the organizational context that encompasses the organizational environment and climate, such as organizational restructuring, new management processes, and initiatives, as well as the psychological climate of the organization (Schaufeli \& Bakker, 2004). These factors may be powerful in shaping employees' level of work engagement. Few studies were focusing on the distal or contextual organizational factors such as organizational culture and leadership, in predicting work engagement (Albrecht, Bakker, Gruman, Macey, \& Saks, 2015; Schaufeli, 2015; Arifin, Troena, and Rahayu, 2014; Zhu, Avolio, \& Walumbwa, 2009) and the findings were inconclusive. In addition, the influence of distal factors has received little attention among scholars as most of the past studies were focusing on the influence of proximal job resources on work engagement. The distal factors that will be investigated in this study are organizational culture, transformational leadership, and professional development.

\section{Organizational culture}

Organizational culture is defined as 'holistic, historically determined, related to anthropological concepts, socially constructed, soft, and difficult to change' (Hofstede, Neuijen, 
Ohayv, \& Sanders, 1990, p.286). It is about the collective programming of the mind as the software of the organization and is manifested through practices (Hofstede, 1991). The organizational culture differentiates one organization from another. The interaction between employees and organizational culture determines the nature of employees' work experience (Shuck, Rocco, \& Albornoz, 2011). Organization culture that is reflected in the working processes, problem-solving processes, and the relationship between employees in an organization is positively related to their employees' work engagement (Biggs, Brough, and Barbour, 2014). Such culture will make employees feel safe and have more trust in their team members which ultimately enhance their work engagement (Kahn, 1990; Chughtai, 2013). This finding is supported by Arifin et al. (2014) where their study found that organizational culture is the most significant predictor of work engagement among high school teachers with Islamic background at Jakarta, Indonesia. Past studies found that organizational culture is one of the organizational factors that are related to job involvement, job satisfaction, career satisfaction, and organizational commitment (Batista, Feijo, \& Silva, 2013; Holligan, Wilson, \& Humes, 2011; Babu \& Singh, 1998). Similarly, studies by Albrecht et al. (2015), Biggs et al. (2014), and Bakker, Demerouti, and Sanz-Vergel (2014) also found that organizational culture influence work engagement. Accordingly, we hypothesize:

H1: Organizational culture influences academics' work engagement.

\section{Transformational leadership}

Transformational leadership is defined as leadership behavior that changes the values and norms of the employees, motivating them to perform beyond their own expectations (Yukl, 1989). Bass (1998) conceptualized transformational leadership using four dimensions, i.e. idealized influence, inspirational motivation, intellectual stimulation, and individualized consideration. For example, transformational leaders create a sense of employees' attachment to the job by being fair and recognize employees' good performance (Gibson et al., 2012). The research found that employee who receives inspiration and support, experience work to be more challenging, involving, and satisfying (Pourbarkhordari, Hua, Zhou, \& Pourkarimi, 2016). In addition, employees who are empowered and supported feel more fulfilled psychologically and show a more positive attitude (Hetland et al., 2015). This supported the notion that the presence of transformational leaders contributes towards employee engagement in their tasks (Bakker et al., 2011). It is reported that transformational leadership has been extensively studied and has a significant impact on work engagement in comparison to other types of leadership such as transactional leadership, authentic leadership, and ethical and charismatic leadership (Schaufeli, 2015; Tims, Bakker, \& Xanthopoulou, 2011; Zhu et al., 2009). Furthermore, there is evidence that highlighted the positive relationship between transformational leadership and work engagement (Breevaart et al., 2016; Bezuidenhout \& Cecile, 2012; Tims et al., 2011). Hence, we postulate:

H2: Transformational leadership influences academics' work engagement. 
INTERNATIONAL JOURNAL OF ACADEMIC RESEARCH IN BUSINESS AND SOCIAL SCIENCES

Vol. 8, No. 10, Oct. 2018, E-ISSN: 2222-6990 @ 2018 HRMARS

\section{Professional Development}

Professional development refers to the formal or informal efforts received by the academics to improve their knowledge and skill in the discipline that includes formal efforts such as continuing education courses and workshops offered internally or externally; and less formal attempts such as gathering with colleagues to share expertise (Hardré \& Hardre, 2012). Professional development is important for the development of professional competency in performing R\&D work. This is evident in previous studies which found that professional development programme is positively associated with work engagement (Soo, Mat, \& Al-Omari, 2013; Butter \& Hermanns, 2011). Butter and Hermanns's (2011) study substantiated that employees who have attended professional development program are engaged in their work. Similarly, Khan, Rasli, Khan, and Malik's (2014) study among Pakistanian academics found that the score for disengagement and emotional exhaustion are decreasing when professional development is increasing. This supports that professional development is one of the determinants of work engagement. It enhances individual self-competency and autonomy in performing their job (Deci et al., 2001), and thus enhance their engagement in performing their tasks. In addition, Czajka and McConnell (2016) conducted a case study to assess the effect of professional development on the instructor's work engagement. It was found that it has a positive effect on their professional growth. Therefore, we hypothesize:

H3: Professional development has a positive influence on academics' work engagement.

\section{Methodology}

This study was conducted at the Malaysian Research Universities (MRUs) using the correlational research design. The unit of analysis is academic from all levels that consist of professors, associate professors, and senior lecturers/assistant professors. The proportionate stratified random sampling was adopted to select 377 out of 3507 academics at MRUs. The three strata of academics positions closely represented the academic population in the sampling frame. Academics of MRUs were selected because they involved intensively in research activities that require them to be engaged in their work. Universiti Putra Malaysia (UPM) was excluded from the list of MRUs in this study as the pilot study was conducted at UPM. The self-rated questionnaire was used in the data collection. The research questions were analyzed using descriptive statistics, such as mean, standard deviations, minimum and maximum while the hypotheses were tested with the multiple regressions at 0.05 level of significance. The response rate for the survey was 77.45 percent and the usable responses were 252.

\section{Measures}

\section{Work Engagement}

Work engagement was measured by Job Engagement Scale (JES) by Rich et al. (2010) with minor modification. JES indicates the multidimensionality concept of work engagement, i.e. simultaneous investment of an individual's physical, cognitive, and emotional in work role performance. JES measures the dimension of physical, cognitive and emotional of work engagement and its internal consistency is .97 . 
INTERNATIONAL JOURNAL OF ACADEMIC RESEARCH IN BUSINESS AND SOCIAL SCIENCES

Vol. 8, No. 10, Oct. 2018, E-ISSN: 2222-6990 @ 2018 HRMARS

\section{Organizational culture}

Measure for organizational culture was adopted from the questionnaire developed by Sarros, Gray, Densten, and Cooper (2005). The sample of items are "achievement orientation", "emphasizes innovation", and "being competitive". This study adopted this scale with minor modification. The Cronbach's alpha coefficient for this variable is .86 .

\section{Transformational leadership}

Measure for transformational leadership is adopted from the Global Leadership Questionnaire (GTL) by Carless, Wearing, \& Mann (2000). It is suitable to measure transformational leadership that refers to behaviors of inspiring subordinates. Sample items are 'Communicates a clear and positive vision of the future' and 'Foster trust, involvement and cooperation among team members'. All the items were measured on a 6-point Likert scale ranging from (1) strongly disagree to (6) strongly agree. The Cronbach's alpha coefficient for this variable is .97.

\section{Professional development}

Professional development was measured by the questionnaire developed by Grobler et al. (2014). The items of professional development in this study were focusing on self-transcendence component as it reflects the seeking opportunities to apply skills in a functional area and to continuously develop those skills to a higher level. All items were measured on a 5-point scale from (1) not important to (5) very important. The Cronbach's alpha coefficient for this variable is .68 and it is still acceptable as it is more than 0.60 (Nunnally \& Bernstein, 1994).

\section{Results}

Demographic Variables (Gender, Age, Age during obtaining Ph.D., and Designation)

The results showed that there were more male respondents at the MRUs where males consist of $135(53.6 \%)$ and females 117 (46.4\%). The majority of the respondents were within the age of 4150 years old (44.4\%). 156 (61.9\%) respondents obtained their Ph.D. during the age of 31 - 40 and followed by $49(19.4 \%)$ respondents obtained their Ph.D. qualification between the age of $21-30$ and another $45(17.9 \%)$ respondents between the age of $41-50$. This result shows that the respondents were within their active academic years after obtaining their highest academic qualification. The responses reflect the sampling method, i.e. proportionate stratified sampling where Senior Lecturer/Assistant Professor category was $54.0 \%$ (136) followed by Associate Professors (26.6 \% or $67)$ and Professors (19.4 \% or 49). Majority of the respondents, i.e. 106 (42.1\%) have been in their present position between 6 - 10 years.

\section{Work Engagement of Academics at Malaysian Research Universities}

Work engagement refers to a multidimensional motivational concept that reflects the investment of an individual's physical, cognitive, and emotional energy simultaneously in active and full work performance (Rich et al., 2010, p.619). The level of work engagement was determined by the mean score of the academics' work engagement. The respondents indicate their answers on the Likert scale form. Table 2 shows that academics of Malaysian Research Universities have a high level of work engagement with the mean $5.32(\mathrm{SD}=.506)$. The results also indicate that majority of 
INTERNATIONAL JOURNAL OF ACADEMIC RESEARCH IN BUSINESS AND SOCIAL SCIENCES

Vol. 8, No. 10, Oct. 2018, E-ISSN: 2222-6990 C 2018 HRMARS

academics at MRU, i.e. $96 \%$ (242) have a high level of work engagement and none is reported to have a low level of work engagement.

Table 2: The Level of Work Engagement $(n=252)$

\begin{tabular}{lllll}
\hline Level & $\begin{array}{l}\text { Frequency } \\
(\mathrm{n})\end{array}$ & $\begin{array}{l}\text { Percentage } \\
(\%)\end{array}$ & $\mathrm{M}$ & SD \\
\hline Work Engagement & & & 5.32 & .506 \\
Low $(1.00-2.66)$ & 0 & 0.0 & & \\
Moderate $(2.67-4.33)$ & 10 & 4.0 & & \\
High $(4.34-6.00)$ & 242 & 96.0 & \\
Total & 252 & 100.0 & \\
\hline
\end{tabular}

Correlations and regression between the organizational factors and work engagement of Academics at Malaysian Research Universities

Table 3 shows that the mean for the respondents' $(n=252)$ score for organizational culture was $4.916(\mathrm{SD}=.747)$, transformational leadership was 4.669 ( $\mathrm{SD}=1.072)$, and professional development was 3.967 (SD=.707). The correlation matrix shows that there are positive and low relationships but statistically significant correlations between organizational culture, transformational leadership and professional development with work engagement (see Table 3). The relationships between the predictors are not too high as they are less than .7 (Tabachnick \& Fidell, 2007).

The regression analysis indicates that all three organizational predictors contribute significantly to the variance in work engagement, $F(3,248)=16.299, p=.000$ (see Table 3). The model summary shows that organizational culture, transformational leadership, and professional development explained $16.5 \%$ variance in academics' work engagement. Of the three predictor variables, it was found that organizational culture and professional development have a relatively stronger effect on work engagement, i.e. $(\beta=.239, p<.001)$ and $(\beta=.224, p<.001)$ respectively in comparison to transformational leadership $(\beta=.132, p<.001)$. As can be seen in Table 2 , these three predictor variables scale had significant positive regression weights, indicating that academics who have higher scores on these scales are expected to have higher work engagement. 
INTERNATIONAL JOURNAL OF ACADEMIC RESEARCH IN BUSINESS AND SOCIAL SCIENCES Vol. 8, No. 10, Oct. 2018, E-ISSN: 2222-6990 @ 2018 HRMARS

Table 3: Summary statistics, correlations, and results from the regression analysis

\begin{tabular}{|c|c|c|c|c|c|c|}
\hline \multirow[b]{2}{*}{ Variables } & \multirow[b]{2}{*}{ Mean } & \multirow[b]{2}{*}{ SD } & \multirow{2}{*}{$\begin{array}{l}\text { Correlation } \\
\text { with work } \\
\text { engagement }\end{array}$} & \multicolumn{3}{|c|}{ Multiple regression weights } \\
\hline & & & & $b$ & SE b & $\beta$ \\
\hline $\begin{array}{l}\text { Work engagement } \\
\text { Organizational }\end{array}$ & 5.326 & .506 & & & & \\
\hline Culture & 4.916 & .747 & $.323 * *$ & .162 & .044 & $.239 * *$ \\
\hline $\begin{array}{l}\text { Transformational } \\
\text { leadership }\end{array}$ & 4.669 & 1.072 & $.234 * *$ & .062 & .030 & $.132 * *$ \\
\hline $\begin{array}{l}\text { Professional } \\
\text { development }\end{array}$ & 3.967 & .707 & $.253^{* *}$ & .160 & .042 & $.224^{* *}$ \\
\hline
\end{tabular}

\section{Discussions and Conclusions}

The aim of this study was to examine the level of academics' work engagement and factors predicting work engagement at the Malaysian Research Universities (MRUs). This study concludes that academics at MRUs are engaged and committed to their work. Engaged academics in their work is the reflection of the commitment of the Malaysian government towards education within which the highest national development budget has been allocated so far for university and staff development. The Research Universities were given autonomy in administration, human resources, financial and academic management and student intake. This move made by the Malaysian government has provided a conducive working environment for academics, thus encouraged them to be more engaged in their work. Apart from that, the Key Performance Indicators which have been cascaded to each and every academic enable and inspire them to be more focused and motivated in their work. The same reason also explains why organizational predictors contributed to academics' work engagement.

This study also concludes that distal organizational predictors play important role in providing the motivation and support towards academics work engagement. The presence of a conducive organizational culture, transformational leaders, and opportunities for professional development are key functions for employees to be engaged in their work. The findings of this study are in tandem with previous studies in work engagement which revealed that organizational culture (e.g., Arifin et al., 2014; Bakker et al., 2014), transformational leaders (e.g., Schaufeli, 2015; Tims et al., 2011; Zhu et al., 2009) and professional development (e.g., Khan et al., 2014; Butter \& Hermanns, 2011) are significant predictors in explaining work engagement among different cohort of samples.

A sound organizational culture is pertinent for academics to engage in their work. An organizational culture that involves the way how work is done, the relationship between employees, the relationship between employees and employers shape the conducive environment that enhances academics' work engagement. This conducive organizational culture promotes employees' psychological safety as they are not afraid to express themselves in work role performance (Kahn, 1990). Furthermore, a sound organizational culture also makes employees have more trust in their team members that will enhance their work engagement (Chughtai, 2013). 
Likewise, the presence of transformational leadership also significantly contributes towards academics' work engagement. Pourbarkhordari et al. (2016) argued on the importance of transformational leaders where they inspire employees to be more effective and to perform beyond the targeted goals. Employees who have been empowered and supported feel more fulfilled psychologically and show a more positive attitude (Hetland et al., 2015). In addition, an employee who receives inspiration and support, experience work as more challenging and satisfying which consequently lead them to become highly engaged with the job tasks (Bakker et al., 2011).

Similarly, professional development is a platform for academics to enhance their selfcompetency which is an important foundation for them to perform their work competently (Deci et al., 2001). This is because professional development equips employees to be knowledgeable and skillful in their area of specialization. Employees who have attended professional development programme are enjoying a higher degree of self-competency and autonomy (Deci et al., 2001). They are well socialized to certain activities in their careers that contribute to their competency and high level of confidence for them to engage in the job activities. The professional development programme provides employees with a platform to identify areas that need to be improved. Thus, universities need to be serious to come out with a structured professional development programme for academics that covers the various spectrum from teaching, research, consultancy and service to the community.

\section{Limitations and Recommendations for Future Studies}

There are several limitations of using survey methods such as lack of in-depth information and details, and difficulties in determining the truthfulness of the answers. Taking this issues into consideration, this study adopted scales that have been tested, reliable and valid besides provided clear instructions and guidelines in the questionnaire (Hair et al., 2003). Additionally, the respondents were informed that their self-report data are confidential and anonymous (Podsakoff et al., 2003). This step could minimize response bias which is based on the social standards and norms as well as to solicit responses on some sensitive items particularly that is related to the organizational culture and leaders. Furthermore, causal inferences about the relationships between the predictors and academics' work engagement could not be made as this is a cross-sectional study. Besides that, the study also noted that the results of using this cross-sectional approach may differ according to circumstances.

In order to have a better understanding about work engagement among academics at MRUs, future qualitative research is recommended. This approach would generate knowledge based on individual's experiences relating to work engagement. Besides, the qualitative study offers a different insight in explaining the phenomenon of work engagement. It is also recommended for future study to repeat the present effort using another rigorous approach, such as a longitudinal approach, as to obtain more comprehensive findings that offer another perspective about causality inferences which would add values to the existing body of knowledge about work engagement. Future studies are also encouraged to test this model in different contexts of universities such as non-Research University. Similar studies could also be replicated using different predictors such as demographic factors, personal and job resources as the findings would be very pertinent especially for Human Resource 
INTERNATIONAL JOURNAL OF ACADEMIC RESEARCH IN BUSINESS AND SOCIAL SCIENCES

Vol. 8, No. 10, Oct. 2018, E-ISSN: 2222-6990 @ 2018 HRMARS

Development practitioners as it offers further guidelines and criteria for employees' selection and training purposes.

\section{Corresponding Author}

Roziah Mohd Rasdi. Head of Department, Department of Professional Development and Continuing Education Faculty of Educational Studies, Universiti Putra Malaysia, 43400 Serdang, Malaysia. Email: roziah_m@upm.edu.my

\section{References}

Ahmad, A. R., Farley, A., \& Naidoo, M. (2012). An examination of the implementation of Federal Government Strategic Plans in Malaysian Public Universities. International Journal of Business and Social Science, 3(15), 290-301.

Albrecht, S. L., Bakker, A. B., Gruman, J. A., Macey, W. H., \& Saks, A. M. (2015). Employee engagement, human resource management practices and competitive advantage: An integrated approach. Journal of Organizational Effectiveness: People and Performance, 2(1), 7-35.

Arifin, F., Troena, E. A., \& Rahayu, M. (2014). The Influence of organizational culture, leadership and personal characteristics towards work engagement and its impacts on teacher's performance (A Study on Accredited High Schools in Jakarta). International Journal of Business and Management Invention, 3(1), 20-29.

Babu, A. R., \& Singh, Y. P. (1998). Determinants of research productivity. Scientometrics, 43(3), 309329. http://doi.org/10.1007/BF02457402

Bailey, C., Madden, A., Alfes, K., \& Flecther, L. (2015). The meaning, antecedents, and outcomes of employee engagement: A narrative synthesis. International Journal of Management Reviews, 00, 1-23. http://doi.org/10.1111/ijmr.12077

Bakker, A. B. (2011). An evidence-based model of work engagement. Current Directions in Psychological Science, 20(4), 265-269. http://doi.org/10.1177/0963721411414534

Bakker, A. B., Boyd, C. M., Dollard, M., Gillespie, N., Winefield, A. H., \& Stough, C. (2010). The role of personality in the job demands-resources model: A study of Australian academic staff. Career Development International, 15(7), 622-636. http://doi.org/10.1108/13620431011094050

Bakker, A. B., \& Demerouti, E. (2007). The Job Demands-Resources Model: State of the Art. Journal of Managerial Psychology, 22(3), 309-328. http://doi.org/10.1108/02683940710733115

Bakker, A. B., \& Demerouti, E. (2014). Job Demands-Resources Theory. In P. Y. Chen \& C. L. Cooper (Ed.), Work and Wellbeing (Vol. Volume III, pp. 37-64). Chichester, UK: Wiley-Blackwell. http://doi.org/10.1002/9781118539415.wbwell019

Bakker, A. B., Demerouti, E., \& Sanz-Vergel, A. I. (2014). Burnout and work engagement: The JD-R Approach. Annu. Rev. Organ. Psychol. Organ. Behav, 1, 389-411. http://doi.org/10.1146/annurev-orgpsych-031413-091235

Bakker, A. B., Schaufeli, W. B., Leiter, M. P., \& Taris, T. W. (2008). Work engagement: An emerging concept in occupational health psychology. Work \& Stress, 22(3), 187-200. http://doi.org/10.1080/02678370802393649 
INTERNATIONAL JOURNAL OF ACADEMIC RESEARCH IN BUSINESS AND SOCIAL SCIENCES

Vol. 8, No. 10, Oct. 2018, E-ISSN: 2222-6990 @ 2018 HRMARS

Basarudin, N. A., Yeon, A. L., Yaacob, N., \& Rahman, R. A. (2016). Faculty workload and employment benefits in public universities. International Review of Management and Marketing, 6(S7), 7382.

Bass, B.M. (1998), Transformational leadership. Industrial, military, and educational impact, LEA, Mahwah, NJ.

Batista, M., Feijo, A., \& Silva, F. (2013). Quality management and employees' attitudes: an example from certified enterprises. Management Research: Journal of the Iberoamerican Academy of Management, 11(3), 260-279. http://doi.org/10.1108/MRJIAM-01-2012-0468

Bentley, P. J. (2015). Academic work from a comparative perspective. The University of Twente.

Bezuidenhout, A., \& Cecile, S. (2012). Transformational leadership and employee engagement in the Mining Industry. Journal of Contemporary Management, 10(January).

Biggs, A., Brough, P., \& Barbour, J. P. (2014). Relationships of individual and organizational support with engagement: examining various types of causality in a three-wave Study. Work \& Stress, 28(3), 236-254. http://doi.org/10.1080/02678373.2014.934316

Bland, C. J., Center, B. A., Finstad, D. A., Risbey, K. R., \& Staples, J. G. (2005). A theoretical, practical, predictive model of faculty and department research. Academic Medicine, 80(3), 225-237.

Breevaart, K., Bakker, A. B., Demerouti, E., \& Derkss, D. (2016). Who takes the lead? A multi-source diary study on leadership, work engagement, and job performance. Journal of Organizational Behavior, 37, 309-325. http://doi.org/10.1002/job

Butter, R., \& Hermanns, J. (2011). Impact of experienced professionalism on professional culture in probation. European Journal of Probation, 3(3), 31-42. http://doi.org/10.1177/206622031100300303

Cadez, S., Dimovski, V., \& Groff, M. Z. (2017). Research, teaching and performance evaluation in academia: the salience of quality. Studies in Higher Education, 42(8), 1455-1473. http://doi.org/10.1080/03075079.2015.1104659

Carless, S. A., Wearing, A. J., \& Mann, L. (2000). A short measure of transformational leadership. Journal of Business and Psychology VO - 14, 14(3), 389. http://doi.org/10.2307/25077344

Chughtai, A. A. (2013). Exploring the impact of trust on research scientists' work engagement: Evidence from Irish science research centers. Personnel Review, 42, 396-421. doi:10.1108/PR-06-2011-0097

Czajka, C. D., \& McConnell, D. (2016). Situated instructional coaching: a case study of faculty professional development. International Journal of STEM Education, 3(1), 10. http://doi.org/10.1186/s40594-016-0044-1

Deci, E. L., Ryan, R. M., Gagne, M., Leone, D. R., Usunov, J., \& Kornazheva, B. P. (2001). Need satisfaction, motivation, and well-being in the work organizations of a Former Eastern Bloc Country: A cross-cultural study of self-determination. Personality and Social Psychology Bulletin, 27(8), 930-942. http://doi.org/10.1177/0146167201278002

Dundar, H., \& Lewis, D. R. (1998). Determinants of research productivity in Higher Education. Research in Higher Education, 43(3), 309-329. http://doi.org/10.1007/BF02457402

Frenken, K., Heimeriks, G. J., \& Hoekman, J. (2017). What drives university research performance? An analysis using the CWTS Leiden Ranking data. Journal of Informetrics, 11(3), 859-872. http://doi.org/10.1016/j.joi.2017.06.006 
INTERNATIONAL JOURNAL OF ACADEMIC RESEARCH IN BUSINESS AND SOCIAL SCIENCES

Vol. 8, No. 10, Oct. 2018, E-ISSN: 2222-6990 @ 2018 HRMARS

Gibson, J.L., John M. Ivancevich, James H. Donelly Jr, \& Robert Konopaske. (2012) Organizational: behavior, structure, processes, Fourteenth Ed. New York: Mc Graw-Hill.

Grobler, A., Rudolph, E. C., Bezuidenhout, M. L., Grobler, A., Rudolph, E. C., \& Bezuidenhout, M. L. (2014). Development of a career-enabler framework within a South African higher education institution. Journal of Psychology in Africa, 24(3), 293-298. http://doi.org/10.1080/14330237.2014.906075

Hair, J. F., R. B. Bush, and D. J. Ortinau. 2003. Marketing research within a changing Information environment. New York, NY: McGraw-Hill.

Hardré, P. L., \& Hardre, P. L. (2012). Community college faculty motivation for basic research, teaching research, and professional development. Community College Journal of Research \& Practice, 36(8), 539-561. http://doi.org/10.1080/10668920902973362

Hetland, J., Hetland, H., Bakker, A. B., Demerouti, E., Andreassen, C. S., \& Pallesen, S. (2015). Psychological need fulfillment as a mediator of the relationship between transformational leadership and positive job attitudes. Career Development International, 20(5), 464-481. http://doi.org/http://dx.doi.org/10.1108/09564230910978511

Hofstede, G., Neuijen, B., Ohayv, D. D., \& Sanders, G. (1990). Measuring organizational cultures ; A qualitative and quantitative study across twenty cases. Administrative Science Quarterly, 35(2), 286-316. http://doi.org/10.2307/2393392

Hofstede, G. (1991). Cultures and organizations. Software of the mind. London: McGraw-Hill.

Holligan, C., Wilson, M., \& Humes, W. (2011). Research cultures in English and Scottish university education departments: An exploratory study of academic staff perceptions. British $\begin{array}{llll}\text { Educational } \quad \text { Research 3713-734. } & \text { 30urnal, }\end{array}$ http://doi.org/10.1080/01411926.2010.489146

Idris, M. K. (2011). Over time effects of role stress on psychological strain among Malaysian public university academics. International Journal of Business and Social Science, 2(9), 154-161. http://doi.org/10.1108/14637151211225225

Kahn, W. A. (1990). Psychological conditions of personal engagement and disengagement at work. Academy of Management Journal, 33(4), 692-724. http://doi.org/10.2307/256287

Khan, F., Rasli, A., Khan, S., \& Malik, F. (2014). Job burnout and professional development among universities academicians. Sci. Int. (Lahore), 26(4), 1693-1696.

Macey, W. H., \& Schneider, B. (2008). The meaning of employee engagement. Industrial and Organizational Psychology, 1(1), 3-30. http://doi.org/10.1111/j.1754-9434.2007.0002.x

May, D. R., Gilson, R. L., \& Harter, L. M. (2004). The psychological conditions of meaningfulness, safety, and availability and the engagement of the human spirit at work. Journal of Occupational and Organizational Psychology, 77(Psychology Module), 11-37.

Maslach, C., Schaufeli, W. B., \& Leiter, M. P. (2001). Job burnout. Annual. Rev. Psychol. 2001., (52), 397-422.

Myhre, M. (2014). The effects of personal resources on work engagement. Master Theis. Norwegian University of Science and Technology.

Noor, A., \& Ismail, N. H. (2016). Occupational stress and its associated factors among academician in a research university, Malaysia. Malaysian Journal of Public Health Medicine, 16(1), 81-91.

Nunnally, J. C., and I. H. Bernstein. 1994. Psychometric theory. 3rd ed. New York: McGraw-Hill. 
INTERNATIONAL JOURNAL OF ACADEMIC RESEARCH IN BUSINESS AND SOCIAL SCIENCES

Vol. 8, No. 10, Oct. 2018, E-ISSN: 2222-6990 @ 2018 HRMARS

Podsakoff, P. M., MacKenzie, S. B., Lee, J. Y., \& Podsakoff, N. P. (2003). Common method biases in behavioral research: A critical review of the literature and recommended remedies. Journal of Applied Psychology, 88(5), 879-903. http://doi.org/10.1037/0021-9010.88.5.879

Pourbarkhordari, A., Hua, E., Zhou, I., \& Pourkarimi, J. (2016). How individual-focused transformational leadership enhances its influence on job performance through employee work engagement. International Business and Management, 11(2), 249-261. http://doi.org/10.5539/ijbm.v11n2p249

Rich, B. L., Lepine, J. A., \& Crawford, E. R. (2010). Job engagement: Antecedents and effects on job performance. Academy of Management Journal, 53(3), 617-635. http://doi.org/10.5465/AMJ.2010.51468988

Sarros, J. C., Gray, J., Densten, I. L., \& Cooper, B. (2005). The organizational culture profile revisited and revised: An Australian perspective. Australian Journal of Management, 30(1), 159-182. http://doi.org/10.1177/031289620503000109

Schaufeli, W. B. (2013). Chapter 1: What is engagement? In C. Truss, K. Alfes, R. Delbridge, A. Shantz, \& E. Soane (Eds.), Employee engagement in theory and practice (pp. 1-37). London: Routledge.

Schaufeli, W. B. (2015). Engaging leadership in the job demands-resources model. Career Development International, 20(5), 446-463. http://doi.org/10.1108/CDI-02-2015-0025

Schaufeli, W. B., \& Bakker, A. B. (2004). Job demands, job resources, and their relationship with burnout and engagement: A multi-sample study. Journal of Organizational Behavior, 25(3), 293-315. http://doi.org/10.1002/job.248

Schaufeli, W. B., Salanova, M., Bakker, A. B., \& Gonzales-Roma, V. (2002). The measurement of engagement and burnout : A two sample confirmatory Factor Analytic Approach. Journal of Happiness Studies, 3, 71-92. http://doi.org/10.1023/ A:1015630930326

Seligman, M. E., \& Csikszentmihalyi, M. (2000). Positive psychology. An introduction. The American Psychologist, 55(1), 5-14. http://doi.org/10.1037/0003-066X.55.1.5

Shuck, M. B., Rocco, T. S., \& Albornoz, C. A. (2011). Exploring employee engagement from the employee perspective: implications for HRD. Journal of European Industrial Training. http://doi.org/10.1108/03090591111128306

Soo, L. S., Mat, N., \& Al-Omari, M. (2013). Organizational practices and employee engagement: a case of Malaysia electronics manufacturing firms. Business Strategy Series, 14(1), 3-10. http://doi.org/10.1108/17515631311295659

Tabachnick, B. G., and L. S. Fidell. 2001. Using multivariate statistics. 4th ed. Boston: Allyn and Bacon.

Tims, M., Bakker, A. B., \& Xanthopoulou, D. (2011). Do transformational leaders enhance their followers' daily work engagement? The Leadership Quarterly, 22(1), 121-131. http://doi.org/10.1016/j.leaqua.2010.12.011

Winefield, A. H., \& Jarrett, R. (2001). Occupational stress in university staff. International Journal of Stress Management, 8(4), 285-298. Retrieved from http://ovidsp.ovid.com/ovidweb.cgi?T=JS\&PAGE=reference\&D=psyc7\&NEWS=N\&AN=201119438-004 
Xanthopoulou, D., Bakker, A. B., Demerouti, E., \& Schaufeli, W. B. (2009). Work engagement and financial returns: A diary study on the role of job and personal resources. The British Psychological Society, 82(1), 183-200. http://doi.org/10.1348/096317908X285633

Yukl, G. (1989). Managerial leadership: A review of theory and research. Journal of Management, Vol. 15, No.2, 251-289.

Zhu, W., Avolio, B. J., \& Walumbwa, F. O. (2009). Moderating role of follower characteristics with transformational leadership and follower work engagement. Group \& Organization Management, 34(5), 590-619.

Zigarmi, D., Nimon, K., Houson, D., Witt, D., \& Diehl, J. (2009). Beyond engagement: Toward a framework and operational definition for employee work passion. Human Resource Development Review, 8(3), 300-326. http://doi.org/10.1177/1534484309338171 